Lepr Rev (1987) 58, 105-118

\title{
Studies of reactivity of some Sri Lankan population groups to antigens of Mycobacterium leprae. I. Reactivity to lepromin A
}

\author{
M R M PINTO,* N B ERIYAGAMA* \\ $\&$ V PEMAJAYANTHA $\dagger$ \\ * Department of Microbiology, Faculty of Medicine, University of \\ Peradeniya, Peradeniya; $\dagger$ Division of Biometry, Central Agricul- \\ tural Research Institute, Gannoruwa, Sri Lanka
}

\begin{abstract}
Accepted for publication 14 August 1986
Summary This paper reports a survey of lepromin reactivity in adult population groups in areas at three different elevations (geographical localities) in central Sri Lanka, using a lepromin A with a bacillary content of 3 or $4 \times 10^{7}$ bacilli $/ \mathrm{ml}$. The patterns of reactivity observed with both Fernandez and Mitsuda reactions were clearly bimodal and similar in all areas. The distributions of reactions were divisible into 'non-reactor' ('negative') and 'reactor' ('positive') components. For both Fernandez and Mitsuda reactivity the demarcation between non-reactor and reactor components seemed to be best made at a reaction size of $3 \mathrm{~mm}$. The mode of reactors of the Fernandez reaction was at 3-6 mm, and of the Mitsuda reaction at 5-8 $\mathrm{mm}$. Both types of reactivity showed no change with increase of age. Fernandez reactivity showed no evidence of any change with sex, race, BCG vaccination status or geographical area. Mitsuda reactivity did not seem to be affected by race or geographical area, but there seemed to be possible changes with sex and BCG vaccination status. Even so, there seems to be a trend for higher reaction sizes in males, and the BCG vaccinated, with both types of reactivity.
\end{abstract}

\section{Introduction}

The lepromin test, like the tuberculin test has been in use for a long time, and a large body of literature has accumulated on it. However, because the availability of lepromin had been restricted in earlier years the literature on this test is not as extensive as that on the tuberculin test. Further, the earlier literature has been of reports of investigations carried out using lepromins prepared from Mycobacterium leprae, of human origin, often prepared by individual investigators, and therefore of variable quality. Now, under the auspices of the IMMLEP programme, lepromin of armadillo origin in a standardized preparation is 
available (lepromin A), in larger quantities for research purposes. We report here an investigation of the patterns of sensitivity to lepromin A in Sri Lanka.

\section{Materials and methods}

The populations tested were from three geographically different areas in Sri Lanka, selected for expected differences in tuberculin sensitivity (as it has been shown carlier liat the prevalence of nonspecific mycobacterial sensitization may vary with the altitude and geographic area. ${ }^{1,2}$ The characteristics of the populations tested are summarized in Table 1.

Those tested were unselected members of the adult population (over 12 years of age) who volunteered to permit testing; only approximately one third of the whole population of a geographically defined area, who were eligible for testing, permitted testing. Some individuals who volunteered were excluded where there was a possibility that the results of the test may be interfered with, e.g. pregnancy, atophy, chronic disease states, steroid therapy. Every person who permitted testing, was administered two antigens intradermally using standard techniques, ${ }^{3}$ on the volar aspect of the left forearm at sites 6-7 cm apart.

The antigens used for testing were; 1, lepromin A with a bacillary content of 3 or $4 \times 10^{7}$ bacilli $/ \mathrm{ml}$ (kindly supplied by Dr Hastings of the National Hansen's Disease Centre, Carville, USA) through courtesy of the Chief, Leprosy Section, World Health Organization, Geneva); 2, the Soluble Protein Antigen (SPA) of $M$. leprae, prepared by ultrasonic disruption of the organism, with a protein content of $10 \mu \mathrm{g} / \mathrm{ml}$ (batch CD 19) (kindly supplied by Dr R J W Rees of the IMMLEP M. leprae Bank, Harrow, Middlesex, UK); and 3, Tuberculin PPD-RT 23, 2 TU per dose (Staten Seruminstitut, Copenhagen, Denmark).

The test results were read as the maximum transverse and vertical diameters of induration palpated, at 48 and $72 \mathrm{hr}$ in the case of the Fernandez reaction (of the lepromin test); and at $72 \mathrm{hr}$ in the case of the tests using SPA, or with tuberculin; with the latter the maximum transverse diameter only, was read. ${ }^{3}$ (Erythema was ignored as it was difficult to define clearly, if not impossible to read, in darkskinned individuals.) The Mitsuda reaction of the lepromin test was read (at 28 days) as the maximum transverse and vertical diameters of the nodule observed (palpated). However, in these studies we have used only the transverse diameters of all types of reactivity (see below).

The relationships between the transverse and vertical diameters of the Fernandez and Mitsuda reactions and SPA reactions, and reactivity and age (all continuous variables) were evaluated using regression analysis. The frequency distributions of the Fernandez and Mitsuda reactions of different groups of persons (BCG positive and negative, different sexes and racial groups-all discrete variables) were compared using chi-square tests.

The results presented in this paper are those with the lepromin test only; those with SPA will be described in a subsequent paper. 
Table 1. Characteristics of populations tested

\begin{tabular}{|c|c|c|c|c|c|c|c|c|}
\hline \multirow[b]{2}{*}{ Location } & \multicolumn{3}{|c|}{ Geographic characteristics } & \multirow[b]{2}{*}{$\begin{array}{l}\text { Racial } \\
\text { groups }\end{array}$} & \multicolumn{3}{|c|}{$\begin{array}{l}\text { Numbers tested and read } \\
\text { at } 48 \mathrm{hr} \text { or } 28 \text { days }\end{array}$} & \multirow[b]{2}{*}{ Antigens used } \\
\hline & $\begin{array}{l}\text { Elevation } \\
\text { (meters) }\end{array}$ & $\begin{array}{l}\text { Rainfall } \\
(\mathrm{mm})\end{array}$ & $\begin{array}{l}\text { Main occupations } \\
\text { (agriculture) }\end{array}$ & & BCG - & $\mathrm{BCG}+$ & $\begin{array}{l}\text { Total } \\
\text { tested }\end{array}$ & \\
\hline Pussellawa & 900 & 2230 & $\begin{array}{l}\text { Tea growing } \\
\text { Rice growing }\end{array}$ & $\begin{array}{c}\text { Indian Tamil } \\
\text { and } \\
\text { Sinhalese }\end{array}$ & 140 & 101 & 241 & $\begin{array}{l}\text { (1) Lepromin A } \\
\text { (bacillary content } \\
3 \times 10^{7} \text { bacilli } / \mathrm{ml} \text { ) } \\
\text { (2) Tuberculin }\end{array}$ \\
\hline \multicolumn{9}{|l|}{ Nuwara Eliya } \\
\hline A. Pedro & 1950 & 2230 & $\begin{array}{l}\text { Tea growing } \\
\text { Market gardening }\end{array}$ & Indian Tamil & 98 & 63 & 161 & As at Pussellawa \\
\hline B. Mahagastota & 1800 & & $\begin{array}{l}\text { Tea growing } \\
\text { Market gardening }\end{array}$ & $\begin{array}{c}\text { Indian Tamil } \\
\text { and } \\
\text { Sinhalese }\end{array}$ & 105 & 79 & 184 & $\begin{array}{l}\text { (1) Lepromin A } \\
\text { (bacillary content } \\
4 \times 10^{7} \text { bacilli } / \mathrm{ml} \text { ) } \\
\text { (2) Tuberculin } \\
\text { (3) SPA }\end{array}$ \\
\hline Galagedera & 150 & 2080 & $\begin{array}{l}\text { Mixed cultivation (cocoa, } \\
\text { coconut, coffee and } \\
\text { rice growing) }\end{array}$ & $\begin{array}{c}\text { Sinhalese } \\
\text { and } \\
\text { Indian Tamil }\end{array}$ & 134 & 104 & 238 & $\begin{array}{l}\text { (1) Lepromin A } \\
\text { (as at Mahagastota) } \\
\text { (2) SPA }\end{array}$ \\
\hline Total tested & & & & & 477 & 347 & 824 & \\
\hline
\end{tabular}




\section{Results}

The patterns of reactions observed are presented as frequency distributions as such distributions are easily compared with others. Since there are thought to be basic differences in the genesis of the two types of reactivity (Fernandez and Mitsuda) elicited by the lepromin test, initially these patterns will be considered separately.

The analysis of results showed that the transverse and vertical diameters elicited were highly correlated in both the Fernandez and Mitsuda reactions. Hence, in keeping with the recommendation for the tuberculin test, ${ }^{3}$ we have used only the transverse diameter in frequency distributions etc. Further, both types of reactions showed no change with age (increase of age), showing that reactivity of both types had probably reached maximum levels (for the individual) by the age of 12 years. Hence age as a variable was disregarded in further analysis.

\section{THE MITSUDA REACTION}

Presented in Figure 1 are the patterns of Mitsuda reactivity of the whole population tested, from the three areas tested. (In one geographic area, Nuwara Eliya, two population groups (Pedro and Mahagastota) located three miles apart were tested. Since both groups seemed to show differing patterns of Fernandez

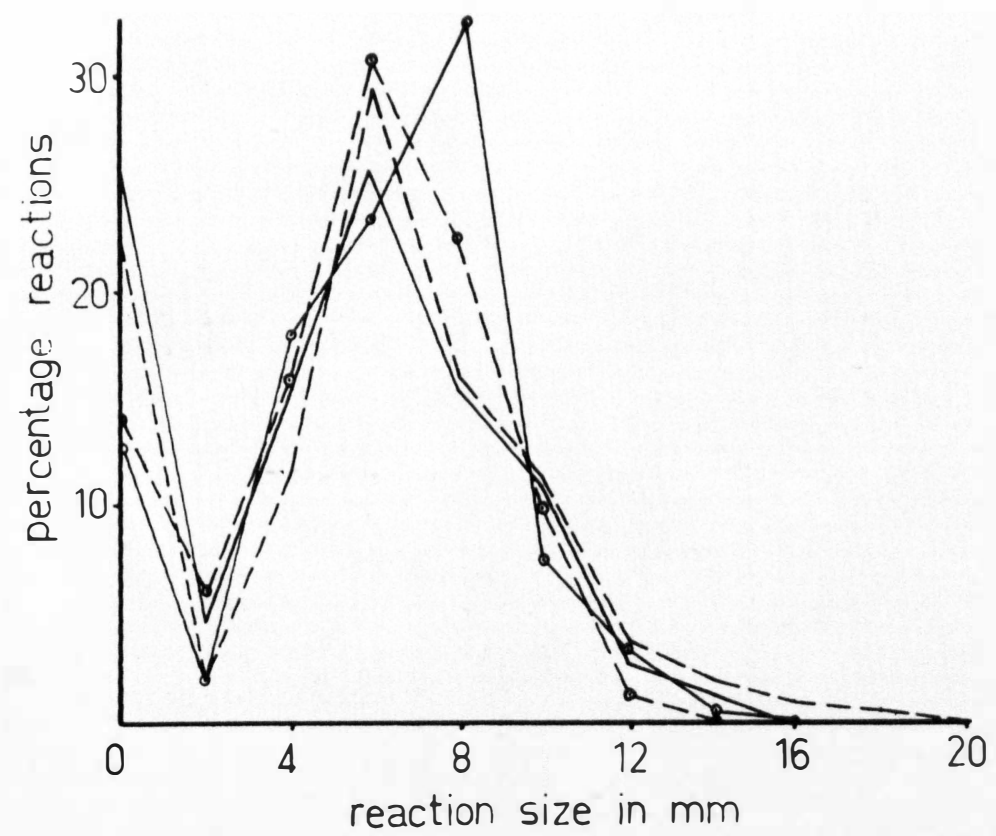

Figure 1. Frequency distributions of Mitsuda reactions of the whole population of the different localities (Pedro, --- $\mathrm{O}---;^{-}$Pussellawa, Mahagastota, Galagedera, $-----)$. 
reactions both are presented as separate population groups.) The overall similarity of the patterns observed in the four groups is marked. The distributions are clearly bimodal with the mode of 'reactors' being at $5 / 6$ to $7 / 8 \mathrm{~mm}$ reaction sizes.

In order to attempt to differentiate between the observed reactor and nonreactor components in Figure 1, a detailed examination of the distribution of reactions in the $0-5 \mathrm{~mm}$ size range was made (Figure 2). This showed that in this investigation, a reaction size of $3 \mathrm{~mm}$ or more could be arbitrarily considered to be a satisfactory level at which to differentiate 'reactors' ('positive') from 'nonreactors' ('negative' $-2 \mathrm{~mm}$ or less).

In Table 2 are presented the means of Mitsuda reactions in the different groups of individuals according to sex, race and BCG vaccination status. The

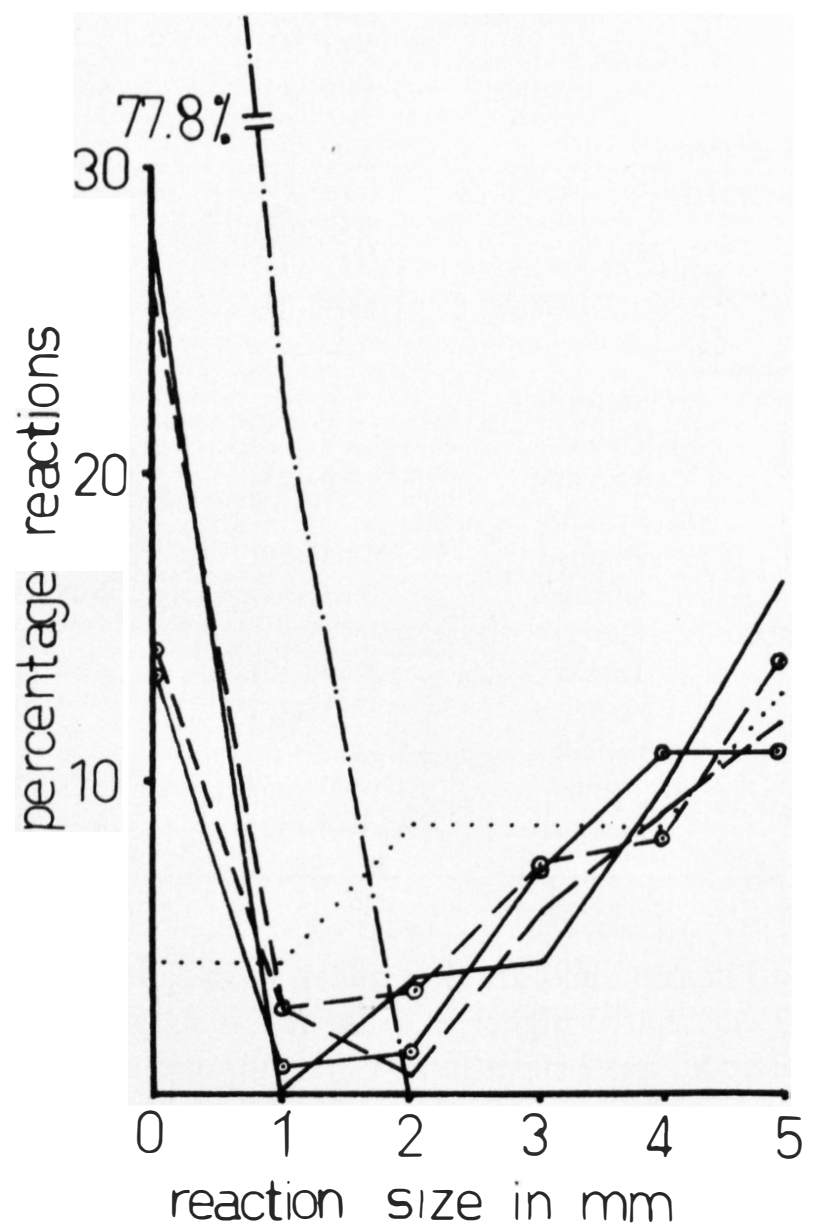

Figure 2. Distribution of Mitsuda reactions of $0-5 \mathrm{~mm}$ of the population in different localities and leprosy patients in Sri Lanka (tuberculoid leprosy, ......; lepromatous leprosy, _ . _ - _; Pedro, --- O---; Pussellawa, —-O_-; Mahagastota, $\longrightarrow$; Galagedera, -- - - - ). 
Table 2. Mean Mitsuda reaction sizes of different categories of subjects

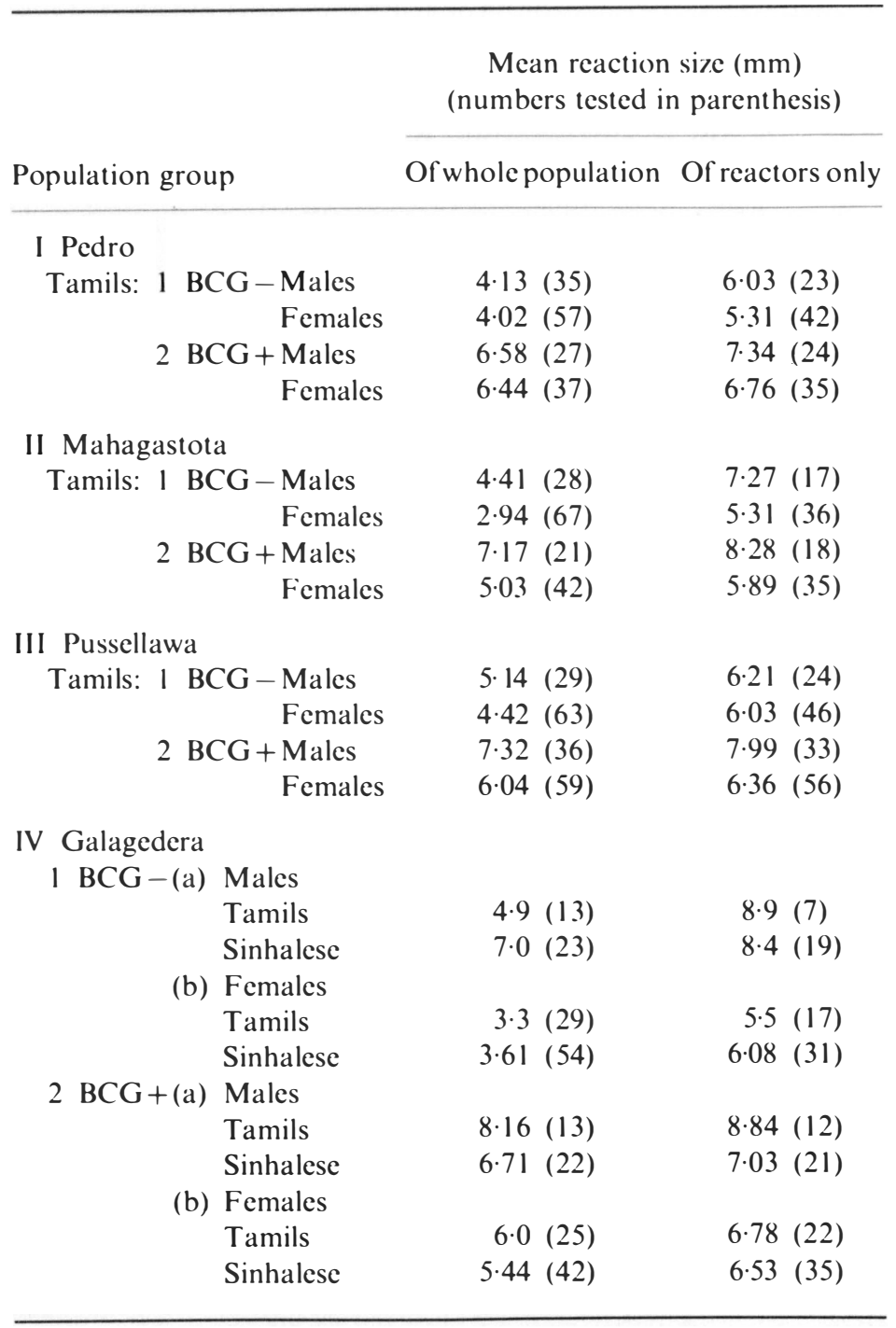

trends that seem to be obtained are that males seem to have higher means than females, the BCG vaccinated higher than those not so vaccinated, and at lower elevation higher than at upper elevations. Where numbers permitted, evaluations were made (using the chi-square test) to determine the possible influence of biological variables on Mitsuda reactivity (Table 3); (examples of comparisons made-BCG + ve male Tamils at Pedro vs BCG + ve female Tamils at Pedro (for sex differences); BCG - ve male Sinhala at Galagedera vs BCG + ve male Sinhala at Galagedera; and so on). Thus at Galagedera all three variables showed no significant differences, while in the other areas the results obtained with different 
Table 3. Influence of sex, race, and BCG vaccination status on Mitsuda reactivity

\begin{tabular}{|c|c|c|c|c|c|c|c|c|c|}
\hline \multirow[b]{4}{*}{ Area } & \multicolumn{9}{|c|}{ Number of groups evaluated showing result } \\
\hline & \multicolumn{3}{|c|}{ Sex } & \multicolumn{3}{|c|}{ Race } & \multicolumn{3}{|c|}{ BCG status } \\
\hline & \multirow{2}{*}{$\begin{array}{c}\text { Not } \\
\text { significant }\end{array}$} & \multicolumn{2}{|c|}{ Significant at } & \multirow{2}{*}{$\begin{array}{l}\text { Not } \\
\text { significant }\end{array}$} & \multicolumn{2}{|c|}{ Significant at } & \multirow{2}{*}{$\begin{array}{c}\text { Not } \\
\text { significant }\end{array}$} & \multicolumn{2}{|c|}{ Significant at } \\
\hline & & $5 \%$ & $1 \%$ & & $5 \%$ & $1 \%$ & & $5 \%$ & $1 \%$ \\
\hline Galagedera & 3 & & & 4 & & & 4 & & \\
\hline Pussellawa & 1 & & 1 & & 1 & & 1 & & 1 \\
\hline Mahagastota & & 2 & & & & & 1 & & 1 \\
\hline Pedro & 2 & & & & & & & 1 & 1 \\
\hline Total & 6 & 2 & 1 & 4 & 1 & & 6 & 1 & 3 \\
\hline
\end{tabular}

groups were inconclusive, with perhaps the exception that there were significant differences between the BCG vaccinated and not vaccinated.

\section{THE FERNANDEZ REACTION}

The frequency distributions of Fernandez reactions of the whole populations in the four different groups are presented in Figure 3. Here, while in three groups there is a general similarity of the patterns of distribution, in one group (at Mahagastota) the pattern differs completely from that of the others. In the latter, there is a marked increase in the small reactions in the $1-2 \mathrm{~mm}$ group, which is not seen elsewhere; the other distributions being of a more or less bimodal pattern of non-reactors and reactors. Except at Mahagastota, the mode of reactors seems to be at $3-4$ or $5-6 \mathrm{~mm}$.

A detailed examination of the distribution of reactions of the smaller sizes $(0-7 \mathrm{~mm})$ (Figure 4) shows that perhaps the best point of separation between the reactor and non-reactor component (except at Mahagastota) could be made at $3 \mathrm{~mm}$ - a reaction of $3 \mathrm{~mm}$ or more therefore being considered to be a 'reactor' ('positive') and $2 \mathrm{~mm}$ or less a 'non-reactor' ('negative').

In Table 4 are presented the means of Fernandez reactions in the different groups of individuals according to sex, race, and BCG vaccination status. Here too, the trends observed seem to be the same as those seen with the Mitsuda reaction (higher in males, in the BCG vaccinated and at lower elevations). The chi-square test was used, here too, to evaluate the influence of the different biological variables on Fernandez reactivity; however no significant differences were shown with sex (number of groups compared, 9), BCG status (number of 


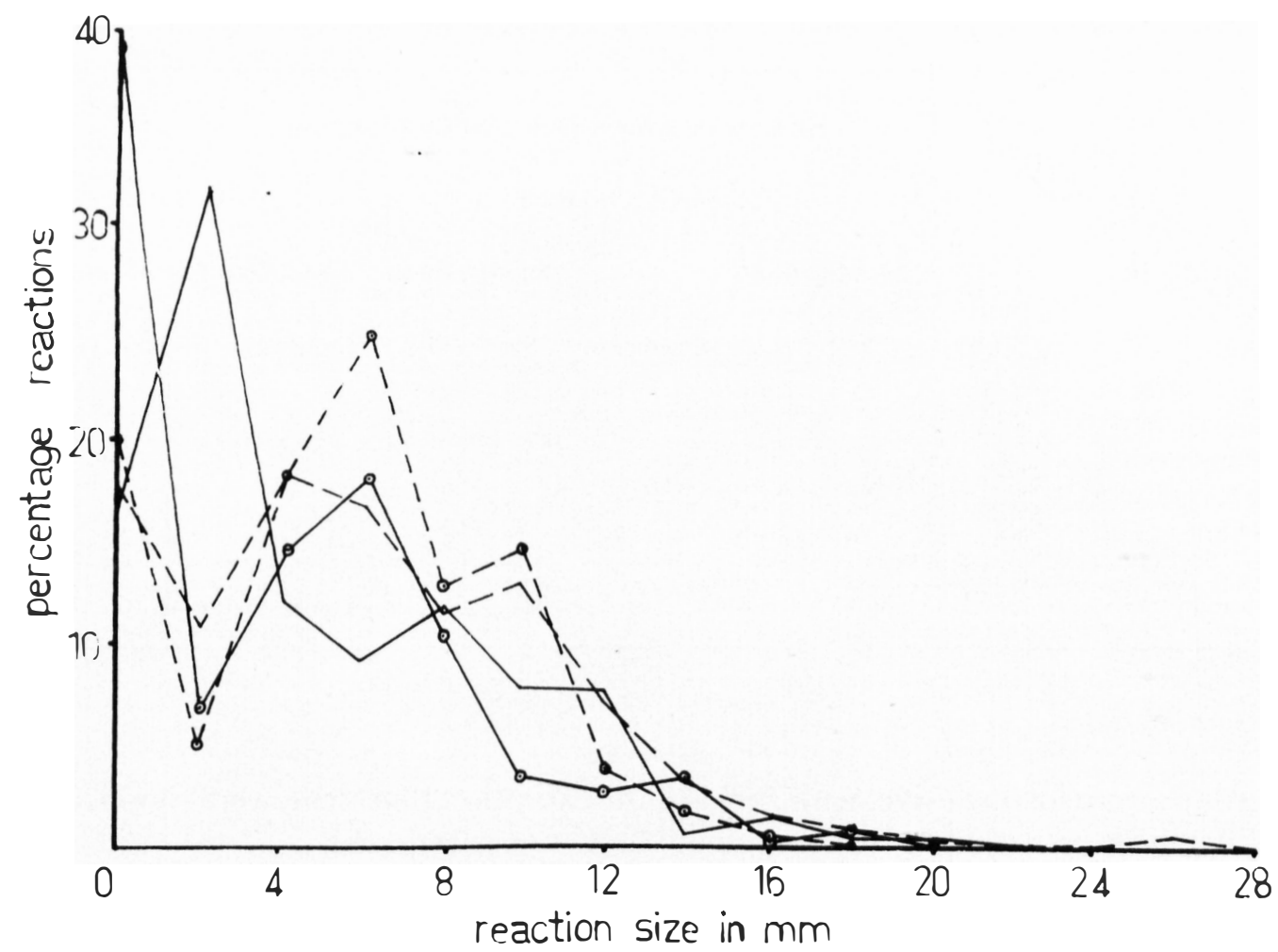

Figure 3. Frequency distribution of Fernandez reactions of the whole population of the different

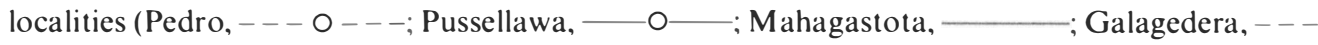
$----)$.

groups compared, 7), or race (number of groups compared, 6, of which one showed differences significant at a $1 \%$ level).

The differences in the frequency distributions of Mitsuda and Fernandez reactions in the different geographical areas were also studied using the chisquare test by comparing the same subjects in the different areas. The results are presented in Table 5.

With Mitsuda reactivity in the BCG positive groups compared in the different areas, no significant differences were found showing that with the BCG vaccinated, all groups showed similar patterns of reactivity. In the BCG negative, out of 12 groups compared, five groups showed differences, with three at a $1 \%$ level and two at a 5\% level. In these comparisons four of the five groups (including all three showing highly significant differences) are among females. Furthermore, four of the six significantly different groups with the Fernandez reaction, and three of the five significantly groups with the Mitsuda reaction, all involve Mahagastota, where it was earlier pointed out that, with the Fernandez reaction, the frequency distribution pattern was dissimilar to that of other areas. If the Mahagastota population is excluded from the comparisons, for Fernandez 


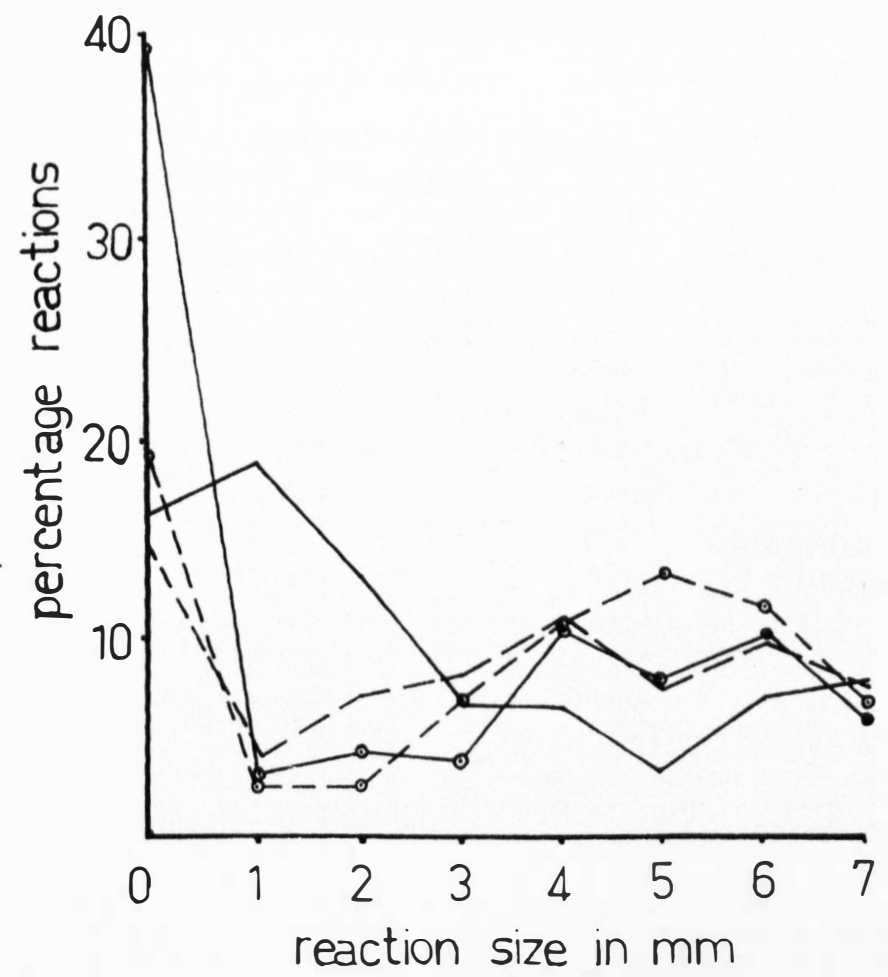

Figure 4. Distribution of Fernandez reactions of $0-7 \mathrm{~mm}$ of the population of the different localities (Pedro, --- O---; Pussellawa, _- O_-; Mahagastota, _—_ Galagedera, ------).

reactivity only one of six groups is significant, and for Mitsuda reactivity only two of eleven groups are significantly different.

\section{OCCURRENCE OF ULCERATION IN THE MITSUDA REACTION}

A factor which may cause individuals not to volunteer for testing during large scale population surveys with skin tests may be the occurrence of painful lesions as a result of testing. Such a lesion would be the occurrence of ulceration, which while not seen in this study with Fernandez reactivity was observed with Mitsuda reactivity. 'Ulceration' as described here, may vary from a minor and innocuous desquamation of the outer layers of the skin to deep and painful surface ulcers, sometimes more than $10 \mathrm{~mm}$ in diameter or sinuses leading to deeper seated cavitory lesions of similar dimensions. The incidence of such 'ulceration' (or desquamation) is presented in Table 6 . While it was not possible to identify relationships of the occurrence of 'ulceration' with sex, age or geographic locality, there seems to be a significant variation with BCG vaccination status - the BCG vaccinated showed a higher incidence of 'ulceration' as compared with those not vaccinated. 
Table 4. Mean Fernandez reaction sizes of different categories of subjects

\begin{tabular}{|c|c|c|}
\hline \multirow[b]{2}{*}{ Population group } & \multicolumn{2}{|c|}{$\begin{array}{c}\text { Mean reaction size }(\mathrm{mm}) \\
\text { (numbers tested in parenthesis) }\end{array}$} \\
\hline & Of whole population & Of reactors only \\
\hline \multicolumn{3}{|l|}{ I Pedro } \\
\hline Tamils: I BCG-Males & $5 \cdot 04(43)$ & $7 \cdot 17(30)$ \\
\hline Females & $4 \cdot 62(61)$ & $6 \cdot 23(44)$ \\
\hline 2 BCG + Males & $6.62(26)$ & $7 \cdot 42(23)$ \\
\hline Females & $5 \cdot 3(34)$ & $6 \cdot 62(27)$ \\
\hline \multicolumn{3}{|l|}{ II Mahagastota } \\
\hline Tamils: I BCG-Males & $4 \cdot 5(24)$ & $6.97(14)$ \\
\hline Females & $3 \cdot 38(74)$ & $6 \cdot 63(32)$ \\
\hline 2 BCG + Males & $7 \cdot 43(20)$ & $10 \cdot 08(14)$ \\
\hline Females & $2 \cdot 9(45)$ & $5 \cdot 84(18)$ \\
\hline Sinhalese: 1 BCG-Males & $3 \cdot 5(3)$ & $4 \cdot 5(2)$ \\
\hline Females & $3 \cdot 55(11)$ & $5 \cdot 25(6)$ \\
\hline 2 BCG + Males & $10 \cdot 15(7)$ & $11 \cdot 59(6)$ \\
\hline Females & $5 \cdot 21(12)$ & $6.45(9)$ \\
\hline \multicolumn{3}{|l|}{ III Pussellawa } \\
\hline Tamils: I BCG-Males & $3.08 \quad(31)$ & $5 \cdot 88(16)$ \\
\hline Females & $2 \cdot 31(71)$ & $6 \cdot 34(24)$ \\
\hline 2 BCG + Males & $4.94(40)$ & $6 \cdot 81(29)$ \\
\hline Females & $4 \cdot 56(46)$ & $7 \cdot 65(27)$ \\
\hline $\begin{array}{rr} & \text { Females } \\
\text { Sinhalese: I } & \text { BCG }- \text { Males }\end{array}$ & $3 \cdot 34(9)$ & $7 \cdot 5(4)$ \\
\hline Females & $5 \cdot 39(38)$ & $7 \cdot 62(26)$ \\
\hline 2 BCG + Males & $2 \cdot 6(5)$ & $6 \cdot 5(2)$ \\
\hline Females & $4 \cdot 56(18)$ & $7 \cdot 32(11)$ \\
\hline \multicolumn{3}{|l|}{ IV Galagedera } \\
\hline Sinhalese: I BCG-Males & $6 \cdot 9(25)$ & $7 \cdot 5(23)$ \\
\hline Females & $4 \cdot 24(59)$ & $6 \cdot 76(35)$ \\
\hline 2 BCG + Males & $7 \cdot 76(25)$ & $9 \cdot 03(21)$ \\
\hline Females & $5 \cdot 68(49)$ & $7 \cdot 39(36)$ \\
\hline Tamils: I BCG-Males & $6 \cdot 74(19)$ & $8 \cdot()(16)$ \\
\hline Females & $4.63(32)$ & $6.84(21)$ \\
\hline 2 BCG + Males & $6 \cdot 19(16)$ & $8 \cdot 0(12)$ \\
\hline Females & $6 \cdot 16(26)$ & $7 \cdot 41 \quad(21)$ \\
\hline
\end{tabular}

\section{OCCURRENCE OF 'SOFT' MITSUDA REACTIONS}

In this study it was noticed that while most Mitsuda reactions were of the characteristic nodules, some had a different character, being soft and sometimes even plaque-like. Since the significance of these were uncertain, these reactions were excluded from the foregoing analysis of Mitsuda reactions. However the 
Table 5. Influence of geographical locality on reactivity to lepromin

Groups on which the comparisons were made

\begin{tabular}{|c|c|c|c|c|c|c|c|}
\hline \multirow{2}{*}{$\begin{array}{l}\text { Areas between } \\
\text { which comparisons } \\
\text { were made }\end{array}$} & \multicolumn{3}{|c|}{ Fernandez test } & \multicolumn{4}{|c|}{ Mitsuda test } \\
\hline & $\mathrm{BCG}+\mathrm{M}$ & $B C G+F$ & $\mathrm{BCG}-\mathrm{F}$ & $\mathrm{BCG}+\mathrm{M}$ & $\mathrm{BCG}+\mathrm{F}$ & $\mathrm{BCG}-\mathrm{F}$ & $\mathrm{BCG}-\mathrm{M}$ \\
\hline \multicolumn{8}{|l|}{ Galagedera } \\
\hline vs Pedro & $\begin{array}{l}\text { Not } \\
\text { significant }\end{array}$ & $\begin{array}{l}\text { Not } \\
\text { significant }\end{array}$ & $\begin{array}{l}\text { Not } \\
\text { significant }\end{array}$ & $\begin{array}{l}\text { Not } \\
\text { significant }\end{array}$ & $\begin{array}{l}\text { Not } \\
\text { significant }\end{array}$ & $\begin{array}{l}\text { Not } \\
\text { significant }\end{array}$ & $\begin{array}{l}\text { Not } \\
\text { significant }\end{array}$ \\
\hline es Mahagastota & $\begin{array}{l}\text { Not } \\
\text { significant }\end{array}$ & $\begin{array}{l}\text { Significant } \\
(1 \%)\end{array}$ & $\begin{array}{l}\text { Significant } \\
(5 \%)\end{array}$ & $\begin{array}{l}\text { Not } \\
\text { significant }\end{array}$ & $\begin{array}{l}\text { Not } \\
\text { significant }\end{array}$ & $\begin{array}{l}\text { Not } \\
\text { significant }\end{array}$ & $\begin{array}{l}\text { Not } \\
\text { significant }\end{array}$ \\
\hline es Pussellawa & $\begin{array}{l}\text { Not } \\
\text { significant }\end{array}$ & $\begin{array}{l}\text { Not } \\
\text { significant }\end{array}$ & & & $\begin{array}{l}\text { Not } \\
\text { significant }\end{array}$ & $\begin{array}{l}\text { Significant } \\
(1 \%)\end{array}$ & $\begin{array}{l}\text { Not } \\
\text { significant }\end{array}$ \\
\hline \multicolumn{8}{|l|}{ Pedro } \\
\hline es Mahagastota & $\begin{array}{l}\text { Not } \\
\text { significant }\end{array}$ & $\begin{array}{l}\text { Significant } \\
(1 \%)\end{array}$ & $\begin{array}{l}\text { Significant } \\
(5 \%)\end{array}$ & $\begin{array}{l}\text { Not } \\
\text { significant }\end{array}$ & $\begin{array}{l}\text { Not } \\
\text { significant }\end{array}$ & $\begin{array}{l}\text { Significant } \\
(5 \%)\end{array}$ & $\begin{array}{l}\text { Not } \\
\text { significant }\end{array}$ \\
\hline es Pussellawa & $\begin{array}{l}\text { Significant } \\
(5 \%)\end{array}$ & $\begin{array}{l}\text { Not } \\
\text { significant }\end{array}$ & & $\begin{array}{l}\text { Not } \\
\text { significant }\end{array}$ & $\begin{array}{l}\text { Not } \\
\text { significant }\end{array}$ & $\begin{array}{l}\text { Significant } \\
(1 \%)\end{array}$ & $\begin{array}{l}\text { Not } \\
\text { significant }\end{array}$ \\
\hline $\begin{array}{l}\text { Mahagastota } \\
\text { is Pussellawa }\end{array}$ & $\begin{array}{l}\text { Not } \\
\text { significant }\end{array}$ & $\begin{array}{l}\text { Significant } \\
(5 \%)\end{array}$ & & $\begin{array}{l}\text { Not } \\
\text { significant }\end{array}$ & $\begin{array}{l}\text { Not } \\
\text { significant }\end{array}$ & $\begin{array}{l}\text { Significant } \\
(1 \%)\end{array}$ & $\begin{array}{l}\text { Significant } \\
(5 \%)\end{array}$ \\
\hline
\end{tabular}

Table 6. Occurrence of 'ulceration' and 'soft reactions' in the Mitsuda reaction

Occurrence of ulceration (percentages within parenthesis of those showing 'typical' Mitsuda reactions)
Occurrence of 'soft reactions' (percentages within parenthesis of all those whose. Mitsuda reactions were read including soft reactions)

\begin{tabular}{|c|c|c|c|c|c|c|c|c|c|c|c|c|c|c|}
\hline \multirow{2}{*}{$\begin{array}{l}\text { Age } \\
\text { group } \\
\text { in years }\end{array}$} & \multicolumn{3}{|c|}{ BCG - ve } & \multicolumn{3}{|c|}{$\mathrm{BCG}+\mathrm{ve}$} & \multirow{2}{*}{$\begin{array}{l}\text { Total of } \\
\text { BCG - ve } \\
\text { and + ve }\end{array}$} & \multicolumn{3}{|c|}{$\mathrm{BCG}-\mathrm{ve}$} & \multicolumn{3}{|c|}{$\mathrm{BCG}+\mathrm{ve}$} & \multirow{2}{*}{$\begin{array}{l}\text { Total of } \\
\text { BCG - ve } \\
\text { and + ve }\end{array}$} \\
\hline & $\mathrm{F}$ & $M$ & Total & $\mathrm{F}$ & M & Total & & $\mathrm{F}$ & $\mathrm{M}$ & Total & $\mathrm{F}$ & $\mathbf{M}$ & Total & \\
\hline$\leqslant 20$ & - & $\begin{array}{c}2 \\
(12)\end{array}$ & $\begin{array}{r}2 \\
(4)\end{array}$ & $\begin{array}{c}6 \\
(18)\end{array}$ & $\begin{array}{c}3 \\
(5)\end{array}$ & $\begin{array}{c}9 \\
(10)\end{array}$ & $\begin{array}{c}11 \\
(8)\end{array}$ & $\begin{array}{c}3 \\
(6)\end{array}$ & $\begin{array}{c}3 \\
(15)\end{array}$ & $\begin{array}{c}6 \\
(9)\end{array}$ & $\begin{array}{c}2 \\
(4)\end{array}$ & $\begin{array}{c}1 \\
(3)\end{array}$ & $\begin{array}{c}3 \\
(3)\end{array}$ & $\begin{array}{r}9 \\
(6)\end{array}$ \\
\hline $21-30$ & $\begin{array}{c}1 \\
\text { (1) }\end{array}$ & $\begin{array}{l}2 \\
\text { (6) }\end{array}$ & $\begin{array}{r}3 \\
(2)\end{array}$ & $\begin{array}{l}2 \\
(5)\end{array}$ & $\begin{array}{c}6 \\
(7)\end{array}$ & $\begin{array}{c}8 \\
(6)\end{array}$ & $\begin{array}{l}11 \\
\text { (4) }\end{array}$ & $\begin{array}{l}11 \\
(9)\end{array}$ & $\begin{array}{c}3 \\
(8)\end{array}$ & $\begin{array}{l}14 \\
(9)\end{array}$ & $\begin{array}{c}4 \\
(5)\end{array}$ & $(0)$ & $\begin{array}{c}4 \\
\text { (3) }\end{array}$ & $\begin{array}{l}18 \\
(6)\end{array}$ \\
\hline $31-40$ & $\begin{array}{c}1 \\
\text { (1) }\end{array}$ & $\begin{array}{l}2 \\
(6)\end{array}$ & $\begin{array}{r}3 \\
(3)\end{array}$ & (0) & $\begin{array}{c}7 \\
\text { (14) }\end{array}$ & $\begin{array}{c}7 \\
(8)\end{array}$ & $\begin{array}{l}10 \\
(5)\end{array}$ & $\begin{array}{c}10 \\
(12)\end{array}$ & $\begin{array}{c}1 \\
(3)\end{array}$ & $\begin{array}{c}11 \\
(10)\end{array}$ & $\begin{array}{c}4 \\
(7)\end{array}$ & $\begin{array}{c}1 \\
(3)\end{array}$ & $\begin{array}{c}5 \\
(5)\end{array}$ & $\begin{array}{l}16 \\
(8)\end{array}$ \\
\hline $41-50$ & $(0)$ & (0) & (0) & $\begin{array}{l}1 \\
\text { (8) }\end{array}$ & $\begin{array}{c}2 \\
(9)\end{array}$ & $\begin{array}{l}3 \\
\text { (9) }\end{array}$ & $\begin{array}{r}3 \\
(3)\end{array}$ & $\begin{array}{c}3 \\
(6)\end{array}$ & $\begin{array}{c}7 \\
\text { (25) }\end{array}$ & $\begin{array}{c}10 \\
(13)\end{array}$ & $\begin{array}{c}2 \\
(8)\end{array}$ & $\begin{array}{c}1 \\
(8)\end{array}$ & $\begin{array}{c}3 \\
(8)\end{array}$ & $\begin{array}{c}13 \\
\text { (11) }\end{array}$ \\
\hline $51-60$ & (0) & $\begin{array}{l}2 \\
(8)\end{array}$ & $\begin{array}{r}2 \\
(5)\end{array}$ & (0) & $(0)$ & (0) & $\begin{array}{r}2 \\
(5)\end{array}$ & (0) & $\begin{array}{c}1 \\
(4)\end{array}$ & $\begin{array}{c}1 \\
(2)\end{array}$ & $(0)$ & $(0)$ & (0) & $\begin{array}{c}1 \\
(2)\end{array}$ \\
\hline$\geqslant 61$ & (0) & (0) & & & & & (0) & $(0)$ & $\begin{array}{c}5 \\
(71)\end{array}$ & $\begin{array}{c}5 \\
(56)\end{array}$ & & & & $\begin{array}{c}5 \\
(56)\end{array}$ \\
\hline Total & 2 & 8 & 10 & 9 & 18 & 27 & 37 & 27 & 20 & 47 & 12 & 3 & 15 & 62 \\
\hline
\end{tabular}




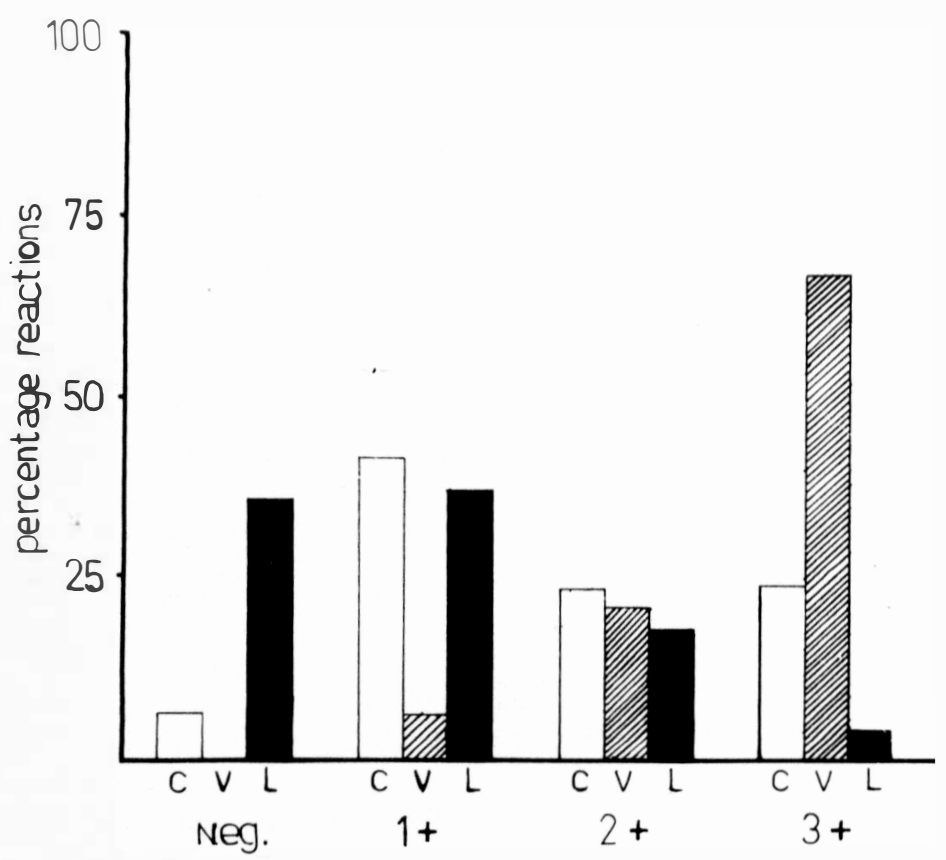

Figure 5. Comparison of Mitsuda reactivity in areas of low endemicity for leprosy in Sri Lanka with a nonendemic area in Chile, and an area for low endemicity in Venezuela. (C, Chile; V, Venezuela; L, Sri Lanka.)

occurrence of these is documented, as they were found in significant numbers (Table 6). While we would hesitate to draw attention to definitive patterns in the incidence of soft reactions, the data presented does seem to suggest that the occurrence of these is less in the BCG vaccinated as compared with those not so vaccinated, in contrast to the pattern of occurrence of ulcerative lesions.

\section{Discussion}

A traditional way of classifying results of the lepromin test, has been into 'positive' or 'negative'. While such a division would be useful in clinical practice, it is less useful from the immuno-epidemiological point of view. Variable criteria for 'positive' and 'negative' have also been used, making comparisons of the work of different investigators more difficult. With bimodal distributions, as those shown by the Mitsuda and Fernandez reactions in this investigation (with one exception), it is easily possible to group the reactions into 'non-reactors' and 'reactors'. With the Mitsuda reaction the definition of a reactor in this investigation agrees well with the criteria for 'positive' ( 3 or $4 \mathrm{~mm}$ or more $)^{4,5,6}$ as defined by other workers. In the case of the Fernandez reaction, the reaction we have read is of induration, and hence different from that by some other workers (which also included erythema). The differentiation of a 'reactor' as decided in this study is at a much smaller reaction size $(3 \mathrm{~mm}$ or more) than that (of a 
'positive') used by other workers ( $10 \mathrm{~mm}$ or more) who also used erythema as an indicator of a reaction.

The effect of different biological variables on components of the reaction to lepromin (Mitsuda and Fernandez), have been studied using the chi-square test. The Mitsuda reaction showed no significant changes with these variables (sex, race, BCG status) at Galagedera (at the lowest elevation); more or less equivocal changes with sex and race at other areas, while more significant changes seemed to appear with BCG vaccination status. Fernandez reactivity in all areas did not seem to be influenced by these variables.

The highest altitude difference was between Galagedera and Nuwara Eliya (Pedro and Mahagastota) - approximately $1800 \mathrm{~m}$. However there were no striking changes in reactivity of both Fernandez and Mitsuda types between the two areas. This and the other evidence presented here, suggests that in Sri Lanka altitude makes no difference to both types of reactivity to lepromin.

Another interesting finding is the fact that there is no change of reactivity with age. This leads to the conclusion that lepromin reactivity has reached maximum levels (for the population) by the age of 12 years.

At Galagedera, at the lowest elevation where populations were tested in this survey, sex, race and BCG vaccination showed no effect on lepromin reactivity of either type. (From earlier reports ${ }^{2}$ it could be expected that this would be the area showing the highest level of environmental (non-specific) mycobacterial sensitization.) This could be because in the latter area, the population being exposed to high levels of non-specific sensitization have reached maximum levels of sensitization that can be evoked by lepromin testing (this suggestion has been made in respect of BCG vaccination, to explain why such vaccination is less effective in tropical areas, as compared with temperate zones). However, if this hypothesis is accepted, this should be manifest with significant differences in sensitization between Galagedera and other areas, which is not seen.

In Figure 5 we present a comparison of our data on Mitsuda reactivity with that of a recent similar study ${ }^{7}$ in a nonendemic area in Chile, and an area with a low endemicity for leprosy in Venezuela in persons 15 years of age and above. The latter study had been carried out using a lepromin containing $16 \times 10^{7}$ bacilli $/ \mathrm{ml}$, four to five times the number of organisms in the preparation used in this investigation. The patterns of reactivity observed in Venezuela and Chile are different from that reported here. It is uncertain whether the differences in the results could be due to differences in antigen content, or to actual differences in reactivity of the different populations.

The necrotic reactions observed with the lepromin test were seen with the Mitsuda reaction, and were reported ${ }^{8}$ to occur in an area of high endemicity for leprosy, but not in a village free of the disease. In this study we have observed necrotic reactions in population groups, free of the disease, in areas of low endemicity for leprosy. Though areas of large tissue swelling, often painful, were observed with Fernandez reactions, no case of vesiculation or ulceration as seen with tuberculin tests ${ }^{9-11}$ were observed. 
A further question posed is the significance of the soft reactions observed at 28 days. One possibility considered is that these are the results of faulty injection techniques - but this does not seem likely, since these reactions like the typical Mitsuda reaction, seems to occur in the same outer layers of the skin. Similar reactions were observed to develop with repeated lepromin testing, ${ }^{12}$ in those who earlier showed typical nodular Mitsuda reactions. This raises the question whether these reactions are aetiologically different from the typical reactions.

\section{Acknowledgments}

This investigation was supported in part by a grant from the Leprosy Section, World Health Organization, Geneva.

We wish to thank Mr D W Dissanayake, Medical Assistant, Mahagastota State Plantation, Nuwara Eliya, and Ms M G Kusumalatha, Medical Assistant, Trafford Hill State Plantation, Galagedera for assistance in carrying out this study; and Ms T M Gamage and Ms M Wijekoon of the Department of Microbiology, Faculty of Medicine, University of Peradeniya, Peradeniya for assistance in data analysis.

\section{References}

1 Bates LE, Busk T, Palmer CE. Research contributions of BCG vaccination programmes. II. Tuberculin sensitivity at different altitudes of residence. Puh Hlth Reps (Wash), 1951; 66: $1427-41$.

2 Pinto MRM, Arseculeratne SN, Uragoda CG, Hemawardane DM. Differential tuberculin testing in rural populations in Ceylon. Tuhercle, 1972; 53: 182-97.

3 World Health Organization. The WHO Standard Tuberculin Test. WHO/TB/Techn. Guide/3, 1963.

4 Dubois A. La reaction de Mitsuda (notice complimentaire) Bull Soc path exot, 1936; 29: 649-51.

${ }^{5}$ Convit J, Azulay RD, Bermudez D, Salgado P. The lepromin test in tuberculous persons in a non-endemic area. Int $J$ Lepr, 1944; 12: 60-4.

6 Azulay RD, Convit J. The Mitsuda test in nonleprous persons in a non-endemic country. Int J Lepr, 1947; 15: 264-6.

7 Convit J, Pinardi ME, Arias Rojas F, Gonzales I, Corey G, Aruelo JJ, Monzon H. Tests with three antigens in leprosy endemic and non-endemic areas. Bull World Health Organ, 1975; 52:2: 193-8.

${ }^{8}$ Dharmendra, Jaikaria SS. Studies on the lepromin test 2. Results of the test in healthy persons in endemic and non-endemic areas. Lepr India, 1941; 13: 40-7.

${ }^{9}$ WHO Tuberculosis Research Office. The 5 TU versus the 10 TU intradermal tuberculin test. Bull World Health Organ, 1955; 12: 169.

${ }^{10}$ WHO Tuberculosis Research Office. Repeated tuberculin tests at the same sites. Bull World Health Organ, 1955; 12: 197.

1 Pinto MRM, Arseculeratne SN, Uragoda CG. Vesiculation-its occurrence in the differential tuberculin test. Cey J Med Sci, 1972; $21: 2:$ 77-84.

12 Pinto MRM, Eriyagama NB. Immunological effects of lepromin testing. I. Effects of repeated lepromin testing. Lepr Rev, 1987; 58, 119-128. 